PENGARUH KONTRASEPSI SUNTIK TERHADAP PENINGKATAN BERAT BADAN DENGAN LAMANYA PENGGUNAAN PADA AKSEPTOR KELUARGA BERENCANA DI PUSKESMAS LOMPOE KOTA PAREPARE

TAHUN 2017

INFLUENCE OF SITUATED CONTRACEPTION ON WEIGHT IMPROVEMENT WITH THE

USE OF USE OF FAMILY PLANNING ACCEPTOR

IN PUSKESMAS LOMPOE CITY PAREPARE

IN 2017

Ayu Irawati

Program Studi Kebidanan, Stikes Mega Buana Palopo

Alamat Korespondensi:

Ayu Irawati

Jln. Glora Mandiri No.17

082194476668

Email: irawati01ayu@gmail.com 


\title{
PENGARUH KONTRASEPSI SUNTIK TERHADAP PENINGKATAN BERAT BADAN DENGAN LAMANYA PENGGUNAAN PADA AKSEPTOR KELUARGA BERENCANA DI PUSKESMAS LOMPOE KOTA PAREPARE
}

\begin{abstract}
ABSTRAK
Sebagian besar peserta KB menggunakan kontrasepsi jangka pendek. Berdasarkan data Dinkes Kota Parepare 2016 proporsi pemakai kontrasepsi suntikan cukup besar yaitu 54,2\%, dikarenakan akses untuk memperoleh pelayanan suntikan relatif lebih mudah. Tujuan dari penelitian ini adalah mengetahui seberapa besar pengaruh penggunaan kontrasepsi suntik terhadap peningkatan berat badan pada akseptor keluarga berencana di Puskesmas Lompoe Kota Parepare.

Teknik sampling dalam penelitian menggunakan teknik purposive sampling, berdasarkan ciri-ciri yang telah ditentukan dalam kriteria inklusi diantaranya Akseptor kontrasepsi suntik telah menggunakan kontrasepsi suntik minimal 5 tahun, tersedia data yang lengkap berupa catatan berat badan sebelum sampai dengan akhir penggunaan kontrasepsi suntik, tidak menggunakan obat pelangsing, dan tidak olahragawan, sebagai sampel sebanyak 41 akseptor KB suntik. Analisis yang dilakukan adalah melakukan uji dengan Chi-square.

dengan signifikansi $p<0,05$, dapat disimpulkan terdapat pengaruh yang signifikan penggunaan kontrasepsi suntik terhadap kenaikan berat badan dan tekanan darah.
\end{abstract}

Kata kunci: kontrasepsi suntik, peningkatan berat badan

Daftar pustaka : 19 (2003-2012)

\section{INFLUENCE OF SITUATED CONTRACEPTION ON WEIGHT IMPROVEMENT WITH THE USE OF USE OF FAMILY PLANNING ACCEPTOR IN PUSKESMAS LOMPOE CITY PAREPARE}

\begin{abstract}
Most KB participants use short-term contraception. Based on data from Parepare City Health Office 2016 , the proportion of users of injectable contraception is quite big, that is $54,2 \%$, because access to get injection service is relatively easier. The purpose of this research is to know how much influence of injecting contraception use to weight gain at family planning acceptor at Lompoe Town Puskesmas Parepare.

The sampling technique used in this research is purposive sampling technique, based on the characteristics that have been determined in the inclusion criteria such as injection contraceptive acceptors have been using injection contraception for at least 5 years, there is complete data in the form of weight record before until the end of use of injectable contraception, Slimming, and no athlete, as a sample of 41 injectable contraceptive acceptors. The analysis performed is to test with Chi-square.

With significance $\mathrm{p}<0.05$, it can be concluded that there is a significant effect of contraceptive use of injections on weight gain and blood pressure.
\end{abstract}

Keywords: injectable contraceptive acceptor, on weight improvement

Bibliography : $19(2003-2012)$ 


\section{PENDAHULUAN}

Keluarga berencana adalah tindakan yang membantu pasangan suami istri untuk menghindari kehamilan yang tidak diinginkan, mendapatkan kelahiran yang memang sangat diinginkan, mengatur interval kehamilan, dan mengontrol waktu saat kelahiran dalam hubungan dengan umur suami istri serta menentukan jumlah anak dalam keluarga (Suratun et al., 2008). KB mempunyai peranan dalam menurunkan resiko kematian ibu melalui pencegahan kehamilan, melalui pendewasan usia hamil, dan menjarangkan kehamilan atau membatasi kehamilan bila anak dianggap sudah cukup. Setiap wanita berhak memperoleh informasi dan mempunyai akses terhadap metode KB yang mereka inginkan, meliputi keefektifan, keamanan, keterjangkauan, dan juga metodemetode pengendalian kehamilan yang tidak bertentangan dengan hukum dan perundangundangan yang berlaku (Pinem, 2009).

Sebagian besar peserta KB mengunakan kontrasepsi jangka pendek yang membutuhkan pembinaan secara rutin dan berkelanjutan untuk menjaga kelangsungan pemakaian kontrasepsi. Proporsi pemakai kontrasepsi suntikan cukup besar yaitu $54,2 \%$, dikarenakan akses untuk memperoleh pelayanan suntikan relatif lebih mudah, sebagai akibat tersedianya jaringan pelayanan sampai di tingkat desa atau kelurahan sehingga dekat dengan tempat tinggal peserta KB.

Semua jenis kontrasepsi memiliki kelebihan dan kekurangan. Kekurangan dari kontrasepsi suntik adalah terganggunya pola haid diantaranya adalah amenorrhea, menoragia dan muncul bercak (spotting), kembalinya kesuburan setelah penghentian pemakaian mengalami keterlambatan, dan peningkatan berat badan (Saifuddin et al., 2003).

Sebuah penelitian menunjukkan kontrasepsi suntik Depo-Provera aman dan memiliki efektivitas yang dinggi, namun banyak pengguna kontrasepsi suntik yang berhenti dikarenakan efek sampingnya berupa gangguan pola haid, kenaikan berat badan, sakit kepala, dan rasa ketidaknyamanan diperut (Naser et al., 2009). Efek samping kontrasepsi suntik yang paling utama gangguan pola haid, sedangkan efek yang lain tidak kalah pentingnya adalah adanya peningkatan berat badan antara $1-5 \mathrm{~kg}$. Penyebab peningkatan berat badannya belum jelas. Kenaikan berat badan, kemungkinan disebabkan karena hormon progesteron mempermudah perubahan karbohidrat dan gula menjadi lemak, sehingga lemak di bawah kulit bertambah, selain itu hormon progesteron juga menyebabkan nafsu makan bertambah dan menurunkan aktivitas fisik (Mudrikati, 2012).

Penelitian tentang lama penggunaan kontrasepsi 3 bulan menunjukkan dari 34 akseptor yang menggunakan $\mathrm{KB}$ suntik 3 bulan kurang dari 1 tahun, dan 36 akseptor yang menggunakan KB suntik 3 bulan lebih dari 1 tahun. Hasil didapatkan 41 responden dengan peningkatan berat badan dan 29 responden tidak mengalami peningkatan berat badan, jadi akseptor yang menggunakan kontrasepsi suntik 3 bulan lebih dari 1 tahun lebih berisiko mengalami peningkatan berat badan (Irianingsih, 2011).

Berdasarkan data dari bidan di Puskesmas Lompoe kota parepare jumlah akseptor kontrasepsi suntik rata-rata perbulan sebanyak 84 orang, pil 23 orang, dan kondom 6 orang, dari data menunjukan bahwa pengguna kontrasepsi suntik menunjukan peringkat pertama dibanding dengan kontrasepsi yang lain. Kontasepsi suntik yang digunakan adalah kontrasepsi suntik jenis 3 bulan yaitu depo medroxy progesterone asetat (DMPA), kontrasepsi suntik digunakan karena harga yang relative terjangkau, mudah, tidak mengganggu menyusi dan aman. Dari uraian diatas maka peneliti menganggap penelitian untuk mengetahui pengaruh penggunaan kontrasepsi suntik dengan peningkatan berat badan untuk dilakukan penelitian.

\section{A. Rancangan}

\section{METODE PENELITIAN}

Metode yang digunakan dalam penelitian ini adalah metode penelitian survei analitik dengan pendekatan cross sectional, dalam penelitian ini sampel ditentukan dengan metode purposive sampling yaitu dengan memilih sampel berdasarkan kriteria inklusi sesuai dengan data yang dibutuhkan dalam penelitian, untuk memperoleh data pertamatama menentukan sampel yang sesuai dengan kriteria inklusi Akseptor kontrasepsi suntik telah menggunakan kontrasepsi suntik minimal 5 tahun, tersedia data yang lengkap berupa catatan berat badan sebelum menggunakan kontrasepsi suntik sampai dengan akhir penggunaan kontrasepsi suntik, tidak menggunakan obat pelangsing, dan tidak olahragawan untuk mengetahui calon sampel masuk kriteria inklusi atau tidak dengan cara memberikan kuesioner yang 
berisi pertanyaan-pertanyaan yang sesuai dengan kriteria inklusi, setelah mendapatkan sampel data diperoleh dari rekam medik akseptor KB suntik.

Penelitian dilakukan untuk mengetahuai ada tidaknya pengaruh penggunaan kontrasepsi suntik terhadap kenaikan berat badan dengan lamanya penggunaan pada akseptor $\mathrm{KB}$ di Puskesmas Lompoe Kota Parepare.

\section{B. Alat Penelitian}

1. Kuesioner

Kuesioner digunakan untuk menentukan populasi masuk atau tidak dalam kriteria inklusi, jika masuk kriteria inklusi maka populasi tersebut masuk dalam sampel. Kuesioner terdiri dari data akseptor $\mathrm{KB}$ berupa lama penggunaan $\mathrm{KB}$, berat badan, riwayat penyakit, dan obat lain yang digunakan akseptor yang dapat mempengaruhi berat badan akseptor.

2. Data Rekam Medik

Data rekam medik berupa data berat badan dan lamanya penggunaan akseptor KB yang digunakan untuk mengetahui ada tidaknya pengaruh penggunaan kontrasepsi suntik terhadap berat badan dengan lamanya penggunaan akseptor KB suntik tersebut.

\section{Populasi dan Sampel}

1. Populasi

Populasi dalam penelitian ini adalah semua akseptor KB yang menggunakan kontrasepsi suntik di Puskesmas Lompoe Kota Parepare dalam bulan Mei sampai Juni tahun 2017 sebanyak 65 orang.

2. Sampel

Sampel dalam penelitian menggunakan teknik purposive sampling, berdasarkan ciri-ciri atau sifat yang telah ditentukan populasi yang masuk dalam kriteria inklusi sebagai sampel sebanyak 41 akseptor KB suntik.

D. Tempat Penelitian

Penelitian dilaksanakan di Puskesmas

Lompoe Kota Parepare.

\section{E. Penentuan Sampel Penelitian}

1. Penentuan Sampel

Sebelum pengambilan data terlebih dulu ditentukan populasi yang masuk dalam kriteria inklusi sebagai sampel, dari 65 populasi yang masuk dalam kriteria inklusi Akseptor kontrasepsi suntik telah menggunakan kontrasepsi suntik minimal
5 tahun, tersedia data yang lengkap berupa catatan berat badan sebelum menggunakan kontrasepsi suntik sampai dengan akhir penggunaan kontrasepsi suntik, tidak menggunakan obat pelangsing, dan tidak olahragawan sebanyak 41 subjek.

2. Pencatatan data rekam medik

Pencatatan data rekam medik berupa berat badan sebelum dan sesudah menggunakan kontrasepsi suntik, di gunakan untuk mengetahui ada atau tidaknya pengaruh penggunaan kontrasepsi suntik terhadap peningkatan berat badan pada akseptor KB suntik.

\section{F. Analisis Data}

Analisis data dimulai dengan mencatat data rekam medik akseptor KB suntik yang berupa data berat badan awal sampai penggunaan kontrasepsi suntik terakhir, kemudian dilakukan analisis univariate. Pertama mengelompokkan akseptor berdasarkan umur, rata-rata umur akseptor adalah $\leq 25,25-35$, dan $>35$ tahun. Kedua mengelompokkan akseptor berdasarkan lama penggunaan kontrasepsi suntik, pengelompokan dibagi menjadi 2 yaitu kelompok penggunaan kontrasepsi 5 tahun dan $>5$ tahun. Ketiga dihitung selisih berat badan dengan cara mengurangi berat akhir dengan berat awal penggunaan kontrasepsi suntik, kemudian dibuat kesimpulan dari hasil itu terjadi kenaikan, tetap, atau terjadi penurunan berat badan.

Data yang diperoleh dari analisis univariat kemudian dilakukan analisis bivariat dengan SPSS for windows 19.0, analisis yang dilakukan adalah melakukan uji dengan Chi-squere, tujuan dari analisis dengan chi-square adalah untuk mengetahui pengaruh penggunaan kontrasepsi suntik terhadap peningkatan berat badan dengan lama penggunaan pada akseptor KB suntik, dengan tingkat signifikansi $\mathrm{p}<0,05$.

\section{HASIL DAN PEMBAHASAN}

\section{A. Gambaran Umum Tempat Penelitian}

Penelitian ini dilakukan di Puskesmas Puskesmas Lompoe Kota Parepare pada bulan Mei sampai Juni 2017. Peserta KB di Puskesmas Lompoe Kota Parepare adalah yang masih aktif menggunakan kontrasepsi 
dari awal penggunaan sampai dengan saat ini, Peserta KB di Puskesmas Lompoe Kota Parepape rata-rata menggunakan non metode kontrasepsi jangka panjang (non MKJP) berupa pil, suntik dan kondom yang mencapai 87,5\% dari keseluruhan peserta $\mathrm{KB}$ dan sisannya menggunakan metode kontrasepsi jangka panjang (MKJP) berupa IUD dan implant.

\section{B. Pemilihan Sampel Berdasarkan Kuesioner}

Sampel dipilih dengan memberikan kuesioner pada populasi yaitu akseptor kontrasepsi suntik di Puskesmas Lompoe Kota Parepare pada bulan Mei-Juni sebanyak 65 orang, dari hasil analisis kuesioner 41 orang yang masuk kriteria sebagai sampel yaitu menggunakan kontrasepsi suntik selama 5 tahun atau lebih, tidak menggunakan kontrasepsi selain kontrasepsi suntik, tidak menggunakan obat pelangsing, tidak melakukan diet, dan bukan seorang olahragawan, sedangkan sisanya 20 orang menggunakan kontrasepsi suntik kurang dari 5 tahun, 2 orang melakukan diet, 2 orang menggunakan kondom sebagai kontrasepsi darurat.

\section{Karakteristik Responden}

Berdasarkan tabulasi data yang diperoleh berikut ini disajikan data berdasarkan karakteristik dari akseptor kontrasepsi suntik:

Tabel 1. Distribusi frekuensi berdasarkan dari karakteristik usia, lama penggunaan, pekerjaan, dan pendidikan terakhir akseptor kontrasepsi suntik di Puskesmas Lompoe Kota Parepare pada bulan MeiJuni (dalam persen)

$\begin{array}{lcc}\text { karakteristi } & \text { Jumlah } & \begin{array}{l}\text { Persenta } \\ \text { se }(\%)\end{array} \\ \text { Umur } & & \\ \text { 21 - 25 tahun } & 4 & 9,8 \% \\ \text { 26 - 35 tahun } & 20 & 48,8 \% \\ \text { > 35 tahun } & 17 & 41,4 \% \\ \text { Lama penggunaan } & & \\ \text { = 5 tahun } & 26 & 65,0 \% \\ \text { > 5 tahun } & 15 & 35,0 \% \\ \text { Pekerjaan } & & \\ \text { Wirausaha } & 31 & 75,6 \% \\ \text { Petani } & 8 & 19,5 \% \\ \text { Pegawai } & 2 & 4,9 \% \\ \text { Pendidikan Terakhir } & \\ \text { SMP } & 14 & 34,1 \% \\ \text { SMA } & 27 & 65,9 \%\end{array}$

Tabel 1 menunjukkan bahwa akseptor kontrasepsi suntik di Puskesmas mayoritas berusia antara 26 - 35 tahun yaitu sebanyak 20 orang atau $48,8 \%$, kemudian $41,4 \%$ berusia lebih dari 35 tahun, dan hanya $9,8 \%$ yang berusia kurang dari 25 tahun, hal ini menunjukan bahwa akseptor $\mathrm{KB}$ suntik kebanyakan berusia subur. Terdapat 26 orang yang menggunakan kontrasepsi suntik selama 5 tahun $(65,0 \%)$, sedangkan 15 orang atau $35,0 \%$ lainnya menggunakan kontrasepsi suntik lebih dari 5 tahun, hal ini menunjukan jarang pengguna kontrasepsi suntik yang menggunakan kontrasepsi suntik lebih dari 5 tahun. Mayoritas akseptor KB suntik yaitu sebanyak 31 orang berwirausaha, 8 orang petani, dan 2 orang pegawai. Terdapat 27 orang akseptor KB suntik yang berpendidikan terakhir SMA, sedang sisanya 14 orang pendidikan terakhirnya adalah SMP.

\section{Pengaruh Penggunaan Kontrasepsi Suntik}

1. Pengaruh Penggunaan Kontrasepsi Suntik Terhadap Perubahan Berat Badan

Akseptor KB yang berjumlah 41 orang ada yang mengalami kenaikan dan ada yang mengalami penurunan berat badan, berikut datanya:

Tabel 2. Data Persentase Berat Badan Akseptor Kontrasepsi Suntik Di Puskesmas Lompoe Kota Parepare

\begin{tabular}{|l|c|c|}
\hline & Jumlah & Persentase \\
\hline $\begin{array}{l}\text { Kenaikan/pen } \\
\text { urunan berat } \\
\text { badan }\end{array}$ & 9 & $22,0 \%$ \\
\hline Turun & 11 & $27,0 \%$ \\
\hline Tetap & 21 & $51,0 \%$ \\
\hline Naik & & \\
\hline $\begin{array}{l}\text { Besarnya } \\
\text { kenaikan/pen } \\
\text { urunan berat } \\
\text { badan (kg) }\end{array}$ & 9 & $22,0 \%$ \\
\hline$(-0,1)-(-5,0)$ & 11 & $27.0 \%$ \\
\hline 0 & 17 & $42.5 \%$ \\
\hline $1,0-5,0$ & 4 & $8.5 \%$ \\
\hline $5,1-10,0$ & & \\
\hline
\end{tabular}

Dari tabel 2 dapat dilihat bahwa akseptor kontrasepsi suntik lebih banyak yang mengalami kenaikan berat badan yaitu sebanyak 20 orang atau $48 \%$, dan kebanyakan 
mengalami kenaikan rata-rata $1,0 \mathrm{~kg}$ sampai $5,0 \mathrm{~kg}$.

Analisis chi-squere digunakan untuk mengetahui pengaruh antara lama penggunaan kontrasepsi suntik dengan kenaikan berat badan pada akseptor kontrasepsi suntik. Berdasarkan data hasil analisis data diperoleh nilai $\mathrm{X}^{2}$ hitung sebesar 19,018 dengan $\mathrm{p}=$ 0,000 , sedangkan $\mathrm{X}^{2}$ tabel pada taraf signifikansi 5\% adalah 5,991. Dikarenakan nilai $X^{2}$ hitung $>X^{2}$ tabel yaitu $19,018>5,991$ dengan signifikansi $p<0,05$, maka terdapat pengaruh yang signifikan lama penggunaan kontrasepsi suntik terhadap kenaikan berat badan.

2. Data akseptor kontrasepsi suntik yang mengalami penurunan, tetap, dan kenaikan berat badan selama menggunakan kontrasepsi suntik 5 tahun dan lebih dari 5 tahun adalah sebagai berikut:

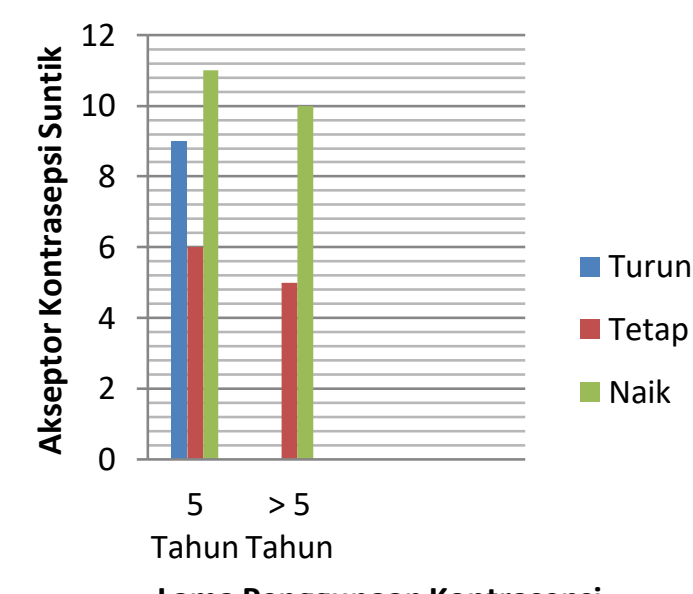

Gambar 1 menunjukkan bahwa dari 26 orang atau $65 \%$ yang menggunakan kontrasepsi suntik selama 5 tahun mayoritas (11 orang atau 27,5\%) berat badannya mengalami kenaikan dan yang mengalami penurunan yaitu 9 orang $(22,5 \%)$ dan hanya 6 orang $(15 \%)$ yang berat badannya tetsp. Selanjutnya dari 15 orang atau $35 \%$ yang menggunakan kontrasepsi suntik lebih dari 5 tahun mayoritas (10 orang atau $25 \%$ ) berat badannya mengalami kenaikan dan hanya 5 orang atau $10 \%$ yang berat badannya tetap. Pola hubungan tersebut menunjukkan bahwa semakin lama penggunaan kontrasepsi suntik maka berat badan semakin mengalami kenaikan. Sebaliknya penggunaan kontrasepsi suntik yang belum terlalu lama maka berat badan tidak mengalami kenaikan.

Kenaikan berat badan disebabkan karena hormon progesteron yang mempermudah terjadinya perubahan gula dan karbohidrat menjadi lemak, sehingga lemak banyak yang bertumpuk di bawah kulit, selain itu DMPA dapat merangsang pusat pengendali nafsu makan di hipotalamus yang dapat menyebabkan akseptor makan lebih banyak dari biasanya akibatnya pemakaian suntikan dapat menyebabkan berat badan bertambah (Hartanto, 2002). DMPA dapat mengaktivasi hormon glukortikoid reseptor dan dalam dosis yang tinggi dapat mengubah metabolisme lemak, hal ini dapat menyebabkan terjadinya penumpukkan lapisan lemak pada manusia yang secara otomatis meningkatkan berat badan (Bakri dan Abdullah, 2008).

Pendapat lainnya menyatakan penggunaan jangka panjang kontrasepsi suntik dapat memicu terjadinya peningkatan berat badan, kanker, gangguan emosi, dan jerawat karena penggunaan suntikan hormonal yang lama dapat mengganggu keseimbangan hormon estrogen dan progesteron dalam tubuh sehingga mengakibatkan terjadi perubahan sel yang normal menjadi tidak normal. Risiko kenaikan berat badan kemungkinan disebabkan karena hormon progesteron yang mempermudah perubahan karbohidrat dan gula menjadi lemak, sehingga lemak di bawah kulit bertambah, selain itu hormon progesteron juga menyebabkan nafsu makan bertambah dan menurunkan aktivitas fisik, akibatnya pemakaian kontrasepsi suntik dapat menyebabkan berat badan bertambah (Saifuddin, 2006).

Pertambahan berat badan memang tidak terlalu besar, antara kurang dari $1 \mathrm{~kg}$ sampai $5 \mathrm{~kg}$ dalam tahun pertama penyuntikan. Penyebab pertambahan berat badan karena bertambahnya lemak tubuh. Para ahli mengatakan kontrasepsi suntik khususnya depo metroxy progesterone asetat (DMPA) merangsang pusat pengendali nafsu makan di hipotalamus, yang menyebabkan akseptor makan lebih banyak dari biasanya (Hartanto, 2004).

\section{E. Keterbatasan Penelitian}

1. Penelitian ini hanya terbatas pada responden peserta KB di Puskesmas 
Lompoe Kota Parepare, sehingga hasil penelitian tidak dapat digeneralisasikan pada peserta KB di daerah lain.

2. Masih banyak faktor lain yang mempengaruhi berat badan dan tekanan darah diantaranya pola makan, stress, dan perilaku masing-masing akseptor kontrasepsi suntik.

\section{PENUTUP}

\section{A. Kesimpulan}

Dari hasil analisis dan pembahasan yang telah diuraikan, maka dapat diambil kesimpulan sebagai berikut:

1. Akseptor kontrasepsi suntik di Puskesmas Lompoe Kota Parepare mayoritas mengalami kenaikan berat badan yaitu sebanyak 21 orang $(51,0 \%)$.

2. Terdapat pengaruh penggunaan kontrasepsi suntik terhadap kenaikan berat badan. Terbukti dari hasil analisis Chi-Square memperoleh nilai yaitu $19,018>5,991$ dengan signifikansi $p<0,05$.

\section{B. Saran}

Saran yang dapat diberikan adalah:

1. Bagi Puskesmas dan tenaga kesehatan diharapkan memberikan informasi tentang keuntungan dan kerugian alat kontrasepsi, sehingga para akseptor KB dapat memilih alat kontrasepsi sesuai kebutuhan.

2. Bagi akseptor KB diharapkan mempertimbangkan berbagai alternatif alat kontrasepsi dengan melakukan perbandingan efek samping dari pemakaian alat kontrasepsi dalam jangka panjang di kemudian hari.

3. Hasil penelitian ini dapat menjadi bahan referensi bagi penelitian berikutnya, karena masih banyak faktor yang mempengaruhi berat badan pada akseptor $\mathrm{KB}$.

\section{DAFTAR ACUA}

Bakri, S., dan Abdullah, A., 2008, Effect of Depot Medroxyprogesterone (DMPA) on Body eight and Serum Lipid Provile in Adult Female Rats, Journal of Biochemistry \& Molecular Biology,2:1
Dinas Kesehatan Sulsel, 2015, Profil kesehatan provinsi Sulawesi Selatan tahun 2015, Makassar: Dinas Kesehatan RI.

Handayani, S., 2010, Buku Ajar Pelayanan Keluarga Berencana, Yogyakarta: Pustaka Rihama.

Hartanto, H., 2009, Keluarga Berencana dan Kontrasepsi, Jakarta: Pustaka Sinar Harapan

Irianingsih, H., 2011, hubungan Lama Pemakaian KB Suntik 3 Bulan Depo Progestin dengan Peningkatan Berat Badan pada Akseptor KB di Puskesmas Klego II Kabupaten Boyolali, Skripsi, Fakultas Kedokteran, Universitas Muhammadiyah Surakarta.

McKinley Health Center, 2008, Factors that Affect Blood Pressure, The Board of Trustees of the University of Illinois, 3:026.

Machfoedz, I., 2006, Statistik Induktif Bidang Kesehatan, Keperawatan, dan Kebidanan (Bio Statistik), Yogyakarta: Penerbit Fitramaya.

Mudrikatin, S., 2012, Hubungan Kontrasepsi KB Suntik 3 Bulan DMPA pada Akseptor KB dengan Peningkatan Berat Badan di Puskesmas Jabon Jombang, Sain Med Jurnal Kesehatan, 4:1.

Naser, M., Ehab, S.A., \& Ahmed, S.G., 2009, Why do depo provera users discontinue?, Journal of the royal medical services, 16:3.

Notoatmodjo, S., 2010, Metode Penelitian Kesehatan, Jakarta: Rineka Cipta.

Pinem, S., (2009), Kesehatan reproduksi dan kontrasepsi, Jakarta: Trans Info Media.

Saifuddin, A.B., B. Affandy, \& Enriquito, R. LU., 2003, buku Panduan Praktis Pelayanan Kontrasepsi edisi 1, Jakarta: Yayasan Bina Pustaka Prawirohardjo.

Saifuddin, A.B., B. Affandy, \& Enriquito, R. LU., 2003, buku Panduan Praktis Pelayanan Kontrasepsi edisi 1, Jakarta: Yayasan Bina Pustaka Prawirohardjo.

Sanger, O.G., Loho, M.F., \& Wirasti, C.R., 2008, Pengaruh Depo Medroxy Progesterone Asetat Terhadap Profil Lipid, Maj obstet ginekol indones, 32:3

Saseen, J.J., \& Maclaughlin, E.J., 2008,Cardiovaskuler disorder: Hipertension, Editor: Dipiro, J.T., Talbert, R.L., Yee, G.C., Matzke, G.R., Wells, B.G., Posey, L. M., Pharmacotherapy A Pathophysiological Approach, Seventh Edition, New York: Mcgraw-Hill Medical Publishing Division. 
Siswosudarmo, H.R., Anwar, H.M., \& Emilia, O., 2007, Teknologi Kontrasepsi, Yogyakarta: Gajah Mada University Press. Sulistyawati, Ari, 2011, Pelayanan Keluarga Berencana, Jakarta: Salemba Medika.

Suratun, S. Heryani, \& Manurung, S., 2008, Pelayanan Keluarga Berencana dan Pelayanan Kontrasepsi, Jakarta: Trans Info Media

Varney, Helen, 2006, Asuhan Kebidanan, Jakarta : EGC. 